Peer-Reviewed Article

ISSN: 2162-3104 Print/ ISSN: 2166-3750 Online

Volume 6, Issue 2 (2016), pp. 565-587

(C) Journal of International Students

http://jistudents.org/

\title{
An Institutional Three-Stage Framework: Elevating Academic Writing and Integrity Standards of International Pathway Students
}

\author{
Donna M. Velliaris \\ Eynesbury Institute of Business and Technology (Australia) \\ Paul Breen \\ The University of Westminster (UK)
}

\begin{abstract}
In this paper, the authors explore a holistic three-stage framework currently used by the Eynesbury Institute of Business and Technology (EIBT), focused on academic staff identification and remediation processes for the prevention of (un)intentional student plagiarism. As a pre-university pathway provider-whose student-body is $98 \%$ "international"-plagiarism is a prevalent and complex issue that cannot be solved with a single-solution response. The three-stages of identification should be conceived holistically and with each stage being equally important to the assessment of student writing. It is worth noting, however, that the extent to which plagiarism is detected will determine the number of stages involved and the degree the student has transgressed. This framework emphasizes the need for, and importance of, Academic Integrity (AI), literary ownership, assessment transparency, and compatibility with partner institutions.
\end{abstract}

Keywords: academic integrity (AI), cheating, misconduct, pathway programs, plagiarism 
Given the dynamics of Higher Education (HE) today, it is becoming less clear that traditional scholastic assessments are still as meaningful and/or relevant as they once were. Nevertheless, presented with the challenge of student plagiarism, HE institutions (HEIs) are devising strategies and/or frameworks to better counter this trend. Previously, EIBT was solely reliant on the vigilance of its markers as custodians of Academic Integrity (AI). Some markers being more observant or better able to recall/trace sources than others meant that the playing field for students was far from even. Unfortunately, this approach had the potential to compromise academic standards and equity of treatment across diploma programs (Yeo \& Chien, 2005). Recognizing the need for a broader, rigorous and more unified approach for dealing with academic misconduct, EIBT has introduced a framework for heightening AI institutionally. The framework presented in this paper is this institute's approach to an increasingly significant sector-wide issue.

Plagiarism has always been a problem in HE, but in this technologically-rich age it is the "breadth of information and services readily available to students via the Internet [that] has significantly increased the scope of the problem and presented new detection challenges" (Savage, 2004). In a cut-and-paste and wireless Internet environment (Horovitz, 2008, p. 232), students have access to multiple and simultaneously accessible online sources making it "easier and faster" (Embleton \& Helfer, 2007, p. 23) than ever before to complete written assignments. Students are thus finding creative and technologically innovative ways to produce text. However, pressures originating in mandated curricula, limited contact hours, testing requirements, and general inertia, make it unlikely that HEIs will abandon summative writing tasks in the near future.

This article outlines a newly implemented conceptual framework; a robust and transparent three-stage approach for investigating and dealing with student plagiarism. This frameworkwhile still being developed theoretically, conceptually, and practically - is proving to be a useful tool and it is envisaged that it will make a valuable contribution to the emerging body of knowledge on Australian "pathway" programs and issues surrounding AI in general. Throughout this paper, the term "international students" or "students" is specific to individuals enrolled on temporary Australian 
student visas and who are almost exclusively from Non-English Speaking Backgrounds (NESB).

\section{BACKGROUND}

EIBT has established its reputation as a quality pre-university pathway provider. International students enter to undertake a Diploma in: Business; Information Technology; or Engineering partnered with either The University of Adelaide or the University of South Australia. Diplomas comprise eight courses that constitute the first-year of a Bachelor's degree at the designated HEI. The majority of lecturing staff teach cross-institutionally - at EIBT and at the partner university - but have the challenge of preparing students who are lower-level in terms of their English language proficiency and/or previous academic results for the requisite language and academic demands of Australian HE. Students are generally between the ages of 17-27 years and represent 20+ nationalities/ethnicities at any one time.

With a contractual agreement to use its partner university's intellectual property, the institution is obliged to deliver identical—or deemed equivalent-learning outcomes and to certify that arrangements/standards are upheld. Articulation and credit transfer agreements are well-established between HEIs. Pathway providers, therefore, offer international students a period of academic language and learning preparation prior to their entry into mainstream Australian HE (Velliaris \& Willis, 2014; Velliaris, Willis, \& Breen, 2015a, 2015b; Velliaris, Willis, \& Pierce, 2015).

\section{LITERATURE REVIEW}

International students' unfamiliarity with academic conventions in an educational context that is little-known may result in plagiarism. For example, in their home country, they may have been taught to not challenge the ideas of an expert author (Leask, 2006; Lund, 2004; Russikoff, Fucaloro, \& Salkauskiene, 2003; Velliaris, Willis, \& Pierce, 2015) and while this type of plagiarism may be innocent and unintended, simply "[t] urning a blind eye" (Park, 2004, p. 291) is not an appropriate professional and educational response. "Unfortunately, such inaction in the face of cheating leads to even higher levels of 
cheating as students quickly become aware of which faculty are not likely to pursue cases of suspected cheating and their courses become targets for cheaters" (McCabe, 2005a).

\section{Writing Assessment in Higher Education}

Writing is the primary method of assessment in Western HE and it is not unusual for a final mark in a course to be based almost entirely on several pieces of writing that are "assessed up to $90 \%$ of the total mark" (Patel, Bakhtiyari, \& Taghavi, 2011, p. 1). Dependence on writing as a measure of competency in a subject can be problematic for international students who may neither be familiar with nor proficient in the skills of writing vis-a-vis the patterns of Australian academic discourse (McLean \& Ransom, 2005; Velliaris \& Warner, 2009). Language proficiency, or lack thereof, is cited by both academics and international students alike as one of the main concerns affecting academic performance (e.g., Martirosyan, Hwang, \& Wanjohi, 2015; Sawir, 2005; Singh, 2015; Zhang \& Mi, 2010). Foreigners transitioning to Australian $\mathrm{HE}$-particularly at the undergraduate level-are required to demonstrate academic proficiency even though they are situated on the periphery of the Australian academic community. The expectation is that they will be able to conform to discipline-specific language requirements having had minimal exposure to their chosen discipline area (Gilbert, 2013; Singh, 2015; Velliaris \& Warner, 2009).

While there is an English language proficiency level below which international students could be at risk of failing, achievement of a minimum score on a proficiency test (e.g., International English Language Testing System (IELTS), the Test of English as a Foreign Language (TOEFL) computer, paper and internet based (iBT) tests, and Pearson Test of English Academic (PTE)) is only a starting point. These tests are not enough to prepare international students for the allround language competency required to undertake tertiary-level studies (McGowan, 2005a, p. 50). It is far from an "appropriate model [of assessment]" for university preparation (Moore \& Morton, 2005, p. 43). Preparing Non-Native Speakers (NNS) for the demands of academic study in an English language environment requires a dual focus of helping them develop the language competency and the study skills that will enable them to succeed. Pointedly, Bosher (2003, 
p. 62) suggested that "[a]cquiring full academic proficiency in a second language can take 8-10 years and even then, residual errors may remain" (see also Martirosyan, et al., 2015).

\section{Contemporary Impact of Technologies}

Today, information is "rapidly accessible 24 hours a day 7 days a week and can be downloaded from the safety and comfort of their own [student] rooms" (Park, 2003, p. 481). Beetham and Sharpe (2007, p. 5) saw the dangers in an "often uncritical attitude to Internet-based information, and the cut-and-paste mentality of a generation raised on editing tools rather than pen and paper". Bonk (2010) pointed out how students may be unacquainted with the notion of drawing on a single best source in their work, and often seek the fastest rather than the deepest answers to their questions. Lea and Jones (2011, p. 377) raised concerns about "undergraduates being so immersed in web-based technologies in their broader lives that they have difficulties engaging in more conventional study practices such as academic reading and writing essays".

Relatedly, cutting and pasting makes it easier to draw on a phenomenon known as "patchwriting", "patchwork plagiarism", "mosaic writing" and/or "plagiaphrasing" (e.g., Abdul-Ameer \& Hussein, 2015; Pecorari, 2003; Stapleton, 2010; Šupak Smolčić \& Bilić-Zulle, 2013). Patchwork plagiarism is defined as taking text portions from several different sources, combining them, and presenting a new composition of old text. As Neville (2010) explained, this technique may be associated with "a transitional writing phase for inexperienced students as they struggle to come to terms with the demands and expectations of a subject and particularly, but not exclusively, if they are trying to do this in a second language" (p. 33). As opposed to other forms of plagiarism that can be detected using Electronic Plagiarism Detectors (EPDs), patchwork plagiarism is much harder to identify. EPDs enable lecturers to compare suspicious student work with published materials and analytical interpretation is simple when there is one or two large and dominant sources from which the text was inappropriately taken. On the contrary, a multitude of smaller bits-and-pieces can still be detected by an EPD, but similarity rates may comprise of many fragments less than $5 \%$ each even though the sum of all percentages may exceed 
10+\% (Šupak Smolčić \& Bilić-Zulle, 2013). Thus, a patchwork plagiarism style may pass "below the radar" and for this reason, software analysis must be coupled with manual checking and careful "human" interpretation.

\section{A Three-Stage Framework}

Preserving the academic credibility and reputation of the institute is paramount and requires a unified response (Batane, 2010), such as currently undertaken within EIBT. "Firstly, we must make the rules of the game clear to the student and secondly, we must assist them to develop skills and strategies to succeed at this new game" (Leask, 2006, p. 191). It may be necessary, therefore, to start from the assumption that plagiarism cannot be totally eliminated (Berry, Thornton, \& Baker, 2006). Thus, strategies to oversee the assessment of writing that minimize the opportunit(ies) for inappropriate behavior may reduce the number and frequency of occurrences.

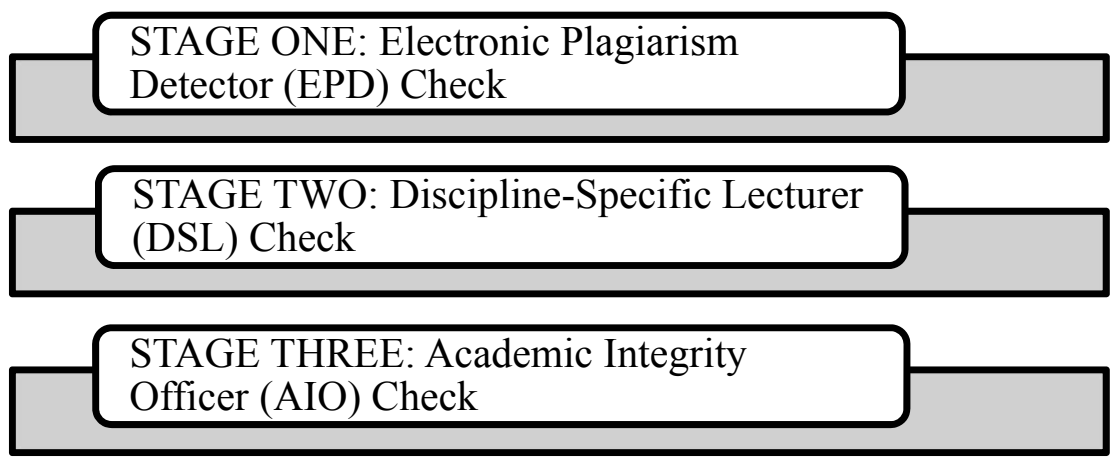

Figure 1. EIBT's three-stages for assessing international students' written work

With this in mind, EIBT is undertaking a three-stage approach to reviewing language-rich assignments submitted across all diploma programs. With reference to Figure 1, the procedure aims to develop students' writing skills and over time promote a consistency of practice so that as they progress from first-year they become more familiar/aware of literacy requirements and appropriate referencing 
conventions for their discipline area (Gourlay \& Greig, 2007, p. 3). Notably, this framework enables a distinction to be made between: (a) inexperienced academic writing and study skills; and (b) deliberate and deceptive academic conduct. The former requires remedial teaching, while the latter is an institutional concern that necessitates documenting and penalty.

\section{Stage One: Electronic Plagiarism Detector (EPD) Check}

The Turnitin ${ }^{\circledR}$ software is the world's most popular EPD (Paynter \& Mills, 2004), although there are other effective EPDs in circulation (Table 1). Today, the ease with which students can access technology to assist with assessment requirements, necessitates tools to assist educators with plagiarism detection, especially as high(er) numbers of students and great(er) degrees of complexity in detection are advantageous. An institutional subscription allows student assignments to be submitted electronically to Turnitin, enabling its database containing many millions of documents, including the contents of online paper mills and websites, to be searched for duplicates (Park, 2004). When student assignments are uploaded to Turnitin, "originality reports" are generated highlighting a student's use of another author(s) words (Batane, 2010).

The function of EPDs is to support the academic who needs to examine the results of originality reports. The days when $\mathrm{HE}$ educators could "justifiably claim to have read all the books and journal articles written in their particular discipline have long gone with such expertise found in ever smaller areas of knowledge" (Goddard \& Rudzki, 2005, p. 59). Somewhat predictably then, "[w]ith billions of articles available on the Internet, it has not been easy for instructors to determine where the international students could have lifted the material from" (Batane, 2010, p. 1) given the impracticality of rigorously scrutinizing every related script (Gannon-Leary, Trayhurn, \& Home, 2009). Although an EPD eliminates much of the practical burden of identifying plagiarized sources, the marker remains responsible for interpreting the percentage of text similarity. Due to its limitations, EPDs have been "criticized because of the lack of 'human' judgement" (Dahl, 2007, p. 175) i.e., the inability to discern between inept citation and intentional plagiarism (Savage, 2004). Notwithstanding studies questioning its usefulness, Turnitin 
and/or other EPDs are likely to remain an important part of the academic environment.

Table 1. Other Electronic Plagiarism Detector (EPD) software

\begin{tabular}{ll}
\hline Attributor & $\begin{array}{l}\text { Measure of Software Similarity } \\
\text { Chimpsky }\end{array}$ \\
CitePlag & PlagiarismDetect \\
Copyscape & Plagiarism-Finder \\
CopyTracker & PlagiServe \\
Dupli Checker & Plagium \\
EduTie & PlagScan \\
Ephorus & PlagTracker \\
eTBLAST & SeeSources \\
EVE2 & Sherlock \\
Ferret & Software Integrity Detection \\
Glatt Plagiarism Self-Detection & (SID) \\
(GPSD) & The Plagiarism Checker \\
iThenticate & URKUND \\
Jplag & VeriGuide \\
\hline
\end{tabular}

Lecturers are expected to inform their students of the procedures for plagiarism detection. Hard-copy papers require a coversheet with a plagiarism declaration signed and dated by the student, whereas a student's username and password is equivalent to their signature and a declaration is implied with electronically submitted work. Submissions void of a cover sheet are not accepted. Despite such measures, students may recognize that if they have plagiarized in the production of an assignment, they would be clever to upload a different piece of work to Turnitin than the one containing the plagiarized content. Though labor intensive, in agreement with Savage (2004), lecturers will only know if another piece of work has been uploaded if electronic copies of assignments are comprehensively compared with any hard-copy paperwork. Relatedly, dot-replacement method can help to stop plagiarism detection from copy-pasted texts. By replacing a space with a dot (.) character and changing the color to paper-white, the text will be analyzed as a longline of text. In response, lecturers should copy-paste the text into a 
plain text box or change all the text color to non-white to identify this trick (Patel, et al., 2011, pp. 3-4).

EIBT lecturers do not give students access to Turnitin reports as this may assist them in devising (other) strategies to avoid detection (Goddard \& Rudzki, 2005, p. 61). When a student requests to revise/re-upload their assignment submission, the entire document is considered a "copy" version as the initial version remains saved to the Turnitin database, thus resulting in a distorted percentage reading (Bretag \& Mahmud, 2009; Patel, et al., 2011). Where duplicates are found, the software returns an annotated document that includes notes related to source documents and color-codes sections of text according to five-point scale ranging from, in ascending order: blue ( $<20$ words); green $(0-24 \%)$; yellow (25-49\%); orange (50-74\%); and red $(75-100 \%)$ to indicate overall similarity.

Each color-coded text links to a source it identifies to allow for direct comparison (Davis, 2007). EIBT lecturers are increasingly cautious and recognize that one cannot assume that all "blue" or "green" assignments are good and "yellow", "brown", "orange" or "red" assignments are bad. While "high" percentage readings are significantly easier to grade, $0 \%$ readings have been associated with intentional misrepresentation/invention of information i.e., falsified research, incorrect or fictitious references, and/or paper-purchasing as the work matches no document in the Turnitin corpus. That is, work submitted by contract cheaters (Table 2) and that have been produced exclusively for student-consumers, may not be found on the Internet and may not be detected using an EPD. Unfortunately for HE, "[s] uch businesses are operating totally legally and they are simply selling goods, in this case essays, reports and coursework" (Mahmood, 2009, p. 1351).

Keuskamp and Sliuzas (2007) and Bretag and Mahmud (2009) hold that while text-matching software can provide educative opportunities, students' academic literacies need further development to benefit from the reports generated by an EPD. Thus, to advance students' ability to manage citation/referencing conventions, lists of rules, examples/exercises, guide books, as well as workshops are regularly and freely provided. Students are also treated relatively leniently for any first offence in order to reinforce the importance of education and prevention within the overall strategy (Park, 2004, p. 
302). Moreover, until the final grades are ratified by the Academic Board, the institution reserves the right to review work retrospectively and to apply appropriate sanctions if there is/are reasonable grounds for investigation and penalty e.g., whistle-blowing by another student(s) (Park, 2004, p. 303).

\section{Table 2. Examples of essay paper purchasing or ghost-writing websites}

123Helpme.com

4TermPapers.com

Cheathouse.com

CustomWritings.com

echeat.com

Editmypaper.ca
EssayGlobe.net

LazyStudents.com

PaperDueNow.com

SchoolSucks.com

unemployedprofessors.com

WowEssays.com

\section{Stage Two: Discipline-Specific Lecturer (DSL) Check}

While EPDs reduce the time-consuming and lengthy process of detecting plagiarism, "what ultimately leads to determinations of plagiarism is considerable manual analysis and subjective judgement" (Bretag \& Mahmud, 2009, p. 54). According to McGowen (2005a, p. $54 ; 2005$ b, p. 291), some academics may claim that their primary concern is that of "content" and that they are not "language" teachers. That is, assisting students linguistically is beyond the scope of their role (Bretag, 2007). In light of workload demands, they have some cause to justify overlooking the additional work involved in providing complex and time-consuming language focus. Nevertheless, the content of disciplines is inextricably bound to the language and the manner in which it is communicated. As described by Nagy and Townsend (2012, p. 97), "[d]iscipline-specific words can be technical or abstract, and understanding them is essential to building conceptual knowledge". Therefore, developing knowledge of technical vocabulary should occur while simultaneously developing knowledge of the overall register of the discipline.

DSLs must be "hyper-astute" (Jones, 2009, p. 9) as they are best placed to identify the structural features and word choices that characterize writing that is acceptable within their discipline. As the 
primary custodians of academic quality, integrity and credibility within a HEI, their commitment to the principles and the practice of an AI framework, such as this one, is crucial. DSLs have a central role to play in plagiarism prevention with responsibility to set appropriate assessment tasks that reduce the likelihood of students having the opportunity to engage in misconduct; "assignments must be more personal and more relevant" (McCabe \& Pavela, 2004, p. 14). Lecturers are responsible for: (a) detecting plagiarism in their coursework; (b) reporting it to the relevant Officer; and (c) producing evidence to substantiate their claim (Park, 2004, p. 295). In general, evidence takes the form of: not answering the question; insufficient in-text citations or no reference to primary source material(s) of the course; reference to sources that students would be unlikely to access; and/or informative content well beyond what could reasonably be expected from a first-year and/or NESB student. If it is suspected that academic misconduct took place, but the student is adamant that they did not plagiarize, they may be required to take part in a viva voce. "Most universities in the UK follow this approach [viva voce] as a matter of course and it is worth the additional effort" (Mahmood, 2009, p. 1356).

Course Coordinators/lecturers have a responsibility to design assessment tasks in such a way as to support AI and minimize opportunit(ies) for academic misconduct. When instances of academic misconduct go undetected, they may appear to be condoned. It has been well-documented that when students believe others are cheating - and their faculty members are ignoring occurrences - they may use this as justification for their own cheating (e.g., Culwin \& Lancaster, 2001; Kisamore, Stone, \& Jawahar, 2007; McCabe, 2005b; McCabe, Butterfield, \& Trevino, 2006; McCabe \& Pavela, 2004; McCabe \& Trevino, 1995; McCabe, Trevino, \& Butterfield, 2001). And, "[w] hen more than a few faculty behave this way, it is hard to convince students that an ethic of integrity exists on campus and cheating can easily become the campus norm" (McCabe, et al., 2001, p. 226). Consequently, seeing peers get away with deceptive practices may produce a sense of injustice that undermines morale among students (Culwin \& Lancaster, 2001). Higbee, Schultz and Sanford (2011, p. 8) found that faculty members who were more proactive with educating students about AI were likely to feel (more) 
comfortable/confident reporting incidents of dishonesty, because they had provided ample and clear guidelines that students should have followed. Conversely, faculty members who ignored incidents of cheating were devaluing the efforts of honest students in demonstrating their acquisition of knowledge.

\section{Stage Three: Academic Integrity Officer (AIO) Check}

Increasingly, HEIs are assigning persons responsible for issues surrounding AI (Table 3). These individuals oversee and facilitate the: consistent application of departmental guidelines on academic conduct; interpretation and implementation of institutional polic(ies); management of reported cases of academic misconduct identified by colleagues; guidelines and supervision of Turnitin; and consistency of outcomes when academic misconduct is proven. The DSL may well be the content specialist, but an AIO for example, is better able to decipher the foreign academic code for students and clearly lay out the necessary steps to fulfil course requirements (Cantell, Scevak, \& Parkes, 2010). For example, comparisons of native and novice corpora of academic writing highlight a number of features of nonnativeness or "unconventionality" in the phraseology of NESB students (Paquot, 2008) that can be used to detect plagiarism.

Stage Two focuses on English for Specific Purposes (ESP). That is, an "understanding of the cognitive, social and linguistic demands of specific academic disciplines" (Hyland \& Hamp-Lyons, 2002, p. 2). Complimentarily, Stage Three is focused on English for Academic Purposes (EAP) whereby academic language is consistent across disciplines e.g., as previously highlighted..., it has been suggested that..., it is worth noting..., the aim of this study..., the extent to which..., the first part of the analysis will examine..., and this study draws on research conducted by... also referred to as "EAP-specific phraseology" (Gilquin, Granger, \& Paquot, 2007, p. 3). NESB students experience a number of problems when composing academic essays/reports with the overuse, underuse and/or misuse of certain writing conventions such as frequency, positioning, register, and semantics (Gilquin, et al., 2007, p. 5 \& 15). Consequently, "[AIOs] bring specific knowledge and experience to the discussion of teaching and learning because on a daily basis they are approached by 
students who share similar concerns and aspirations" (Stratilas, 2011, pp. A-48).

\section{Table 3. Titles for persons in HE responsible for Academic Integrity}

Academic Conduct Advisor Academic Conduct Officer Academic Course Advisor Academic Integrity Advisor Academic Integrity Coordinator Academic Integrity Officer Academic Misconduct Officer Academic Success Coordinator Academic Support Advisor Chief Instructional Officer
Coordinator for Student Conduct

Learning Advisor

Learning Skills Advisor

Responsible Academic Officer

Student Academic Conduct

Officer

Student Learning Advisor

Student Academic Integrity

Coordinator

Student Success Advisor

Students Advisory Officer

If and when the AIO believes a case requires further investigation, they are likely to contact the student to organize a faceto-face meeting (Bretag \& Green, 2009, p. 4). In support of McCabe and Pavela's (2004, p. 15) assertion, "[p]rompt and equitable enforcement of academic-integrity policies does not have to be unduly punitive. Sanctions for first offenses can and generally should have an educational emphasis". According to official policies and procedures, the meeting must occur within 20 working days of the initial notification. Where the student is unable to attend, the discussion may occur via email or teleconference. The student may elect to invite EIBT' s senior student counsellor, any staff member, or student nominee to accompany them. Where a student fails to respond to such notification, the AIO may decide on a course of action without the student being present.

If the AIO determines that no academic misconduct was involved, no further action will be taken and no record of the discussion will be entered on the central database. Where the AIO has determined that there was academic misconduct, they will enter the case into a central database and provide a report to the Course Coordinator and the student within 10 working days. Additionally, the 
AIO will provide academic counselling to the student and may decide on a further course of action, including: resubmission of the assessment task; another outcome appropriate to the case but with an impact less serious than a zero in the assessment component of the course; failure with a zero score in the component of the course; failure in the course; failure in the course and suspension from the program for a period not exceeding one year; suspension for a period not exceeding three years; another outcome appropriate to the case, but with an impact less serious than expulsion; and expulsion.

\section{SUMMARY}

Within this research setting, academic misconduct via plagiarism can occur through students not being familiar with (Western) academic conventions. Allegations of misconduct are considered, therefore, in the context of the extent of the misconduct and the student's underlying intention(s) and/or motivation(s).

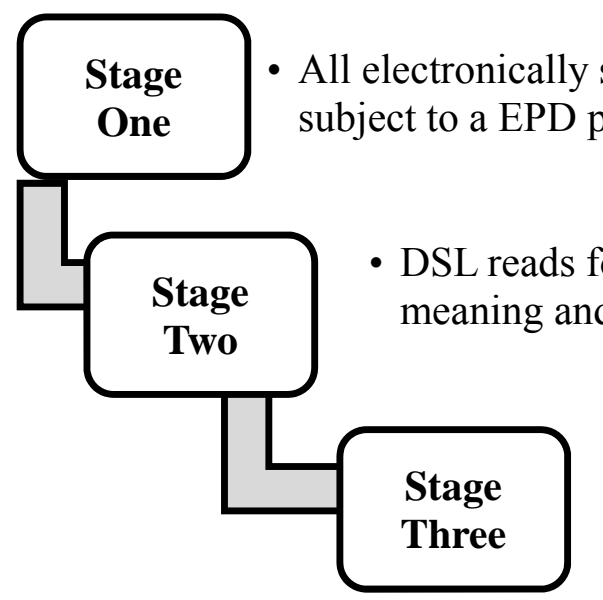

- Suspicious works and random checks are undertaken by the AIO [Pass / Fail]

Figure 2. Summary of progressive steps taken to reach a final assessment result for a student's submission of written work

Additional contextual factors include: academic conventions within the relevant discipline; pre-diploma background; the number of previous offences; the stage/level of program; and any other 
applicable information about the student. In agreement with Culwin and Lancaster (2001, p. 40), "[i]nstitutions that do act proactively run the risk of reducing their student numbers... [however] publicity of the value of their awards long-term should make up for it".

Figure 2 depicts how, with an integrated approach, students are pushed to the level of writing achievement expected at the tertiary-level with the aid of two professionals i.e., the DSL (Stage Two) and the AIO (Stage Three), both of whom work in partnership to enhance and advance students' results. Purposely, as a pathway provider, EIBT must acculturate foreign students striving to enter the "partner" university_-The University of Adelaide or the University of South Australia-which are known to have zero tolerance to academic misconduct.

\section{LIMITATIONS AND FUTURE RECOMMENDATIONS}

The role of Australian HE preparatory pathway programs is substantial for international students. Such students face a range of hurdles related to their adjustment to a new cultural, educational, and social environment, and thus EIBT is adopting a more practical/pragmatic response to its potential to enhance the first-year international student experience, through taking special account of the vulnerabilities of its population. By enhancing the international student experience, EIBT will be better able to address issues that may lead to anxiety and withdrawal. Although this three-stage approach has proven to be an affective starting point, the limitations of this study, include but are not limited to the following two points.

First, it is not possible to give a quantitative measure of the effectiveness in terms of subsequent occurrences of plagiarism. There are many variables that can potentially affect detection rates when comparing different cohorts of students. It seems probable, however, that whatever checks and balances are created, academic misconduct will be present — to some extent — across assessment in HE. Second, it should be acknowledged that the observations shared in this paper are one small part of the complex process of creating effective "pathway" programs. Improving strategies that encourage autonomy, reflection, and performance success, together with appropriately integrated 
language and learning support, may aid in augmenting the potential of all students transitioning to HE.

In terms of future recommendations, as McCabe (2005b, p. 30) expressed "[j] ust as the African tribal maxim proclaims that "it takes a village to raise a child"... it takes the whole campus community - international students, faculty, and administrators- to effectively educate a student". With this in mind, plans to be (re)introduced include (adapted Velliaris, Willis, et al., 2015a):

- Student focus-disseminating information about ethical student behavior via a plethora of outlets e.g., brochures, application for admissions forms, student handbooks, covers of examination booklets, and posters on walls in classrooms; reminding students of assignment expectations prior to submission dates and being explicit/specific about which resources are permitted/not-permitted, together with ongoing use of Turnitin software with guidelines, resources, and lecturer support; delivering focused training to support the development of key academic language and learning skills such as critical analysis, synthesis, evaluation, reflection, and referencing technique; educating students about "intellectual property", why it matters, how to legitimately access scholarly works and protect their own; and highlighting to students that "product" is of less consequence than "process" in the Western educational model.

- Staff focus - ensuring that staff are interculturally competent i.e., at least aware of students' social, cultural and educational backgrounds to be able to provide superior guidance for their academic development; incorporating AI strategies into faculty training/professional development offerings; identifying "root causes" of language learning problems by become more familiar with student' prior educational experiences and beliefs about learning; continuing to provide effective, targeted and ongoing language aid for students whose first language is not the medium of instructionEnglish; and revising policies, procedures and invigilation practices to ensure that students have the understanding of administrators and faculty. 
- Institutional focus - articulating the concept of AI from the Western construct; asking students for input into how to create a community of scholars at the start of each trimester and establishing them as stakeholders in the teaching and learning community; promoting a campus environment that demands ethical behavior by all members of the community by upholding the ethos and values of AI and honesty; and encouraging students to adopt these values in their professional practices. Indeed, the effectiveness of implementing any framework will be influenced by its compatibility with the academic culture of the HEI. In this instance, the framework is essentially positive in its ambitions and has been well-embraced by EIBT.

\section{CONCLUSION}

HE worldwide, as a matter of principle, has a strong commitment to defend its academic credibility and reputation, and protect the standards of its awards. EIBT continues to monitor the impact of the holistic practices it employs by evaluating its procedures for successfully articulating international students to its partner HEIs. The framework discussed in this article is: (a) reducing the prevalence of plagiarism; (b) ameliorating its effects when it does occur; and (c) promoting conditions where plagiarism is risky/unworkable or unthinkable, although forthcoming empirical exploration will endeavor to better quantitatively and qualitatively confirm such assertions.

\section{REFERENCES}

Abdul-Ameer, M. A., \& Hussein, K. S. (2015). Plagiarism and patchwriting detection in EFL students' graduation research writing. Research on Humanities and Social Sciences, 5(8), 128-136.

Batane, T. (2010). Turning to Turnitin to fight plagiarism among university students. Educational Technology \& Society, 13(2), 1-12. 
Beetham, H., \& Sharpe, R. (2007). Rethinking pedagogy for a digital age: Designing and delivering e-learning. New York, NY: Routledge.

Berry, P., Thornton, B., \& Baker, R. (2006). Demographics of digital cheating: Who cheats, and what we can do about it. Paper presented at the Proceedings of the 9th Annual Conference of the Southern Association for Information Systems.

Bonk, C. J. (2010). How technology is changing school. Educational Leadership, 67(7), 60-65.

Bosher, S. (2003). Addressing cultural and linguistic diversity in the classroom: Becoming culturally competent. The Minnesota and Wisconsin Teachers of English to Speakers of Other Languages (The MinneTESOL/WITESOL) Journal, 20, 55-73.

Bretag, T. (2007). The emperor's new clothes: Yes, there is a link between English language competence and academic standards. People and Place, 15, 657-668.

Bretag, T., \& Green, M. (2009, 28-30 September). Determining outcomes for academic misconduct: Is it more important to be consistent or fair? Paper presented at the 4th Asia Pacific Conference on Educational Integrity (4APCEI), University of Wollongong, NSW, Australia.

Bretag, T., \& Mahmud, S. (2009). A model for determining student plagiarism: Electronic detection and academic judgement. Journal of University Teaching \& Learning Practice, 6(1), 4960.

Cantell, R. H., Scevak, J. J., \& Parkes, R. J. (2010). Aligning intellectual development curriculum, instruction and assessment. In R. H. Cantwell \& J. J. Scevak (Eds.), An Academic Life (pp. 16-24). Victoria, Australia: ACER Press.

Culwin, F., \& Lancaster, T. (2001). Plagiarism issues for higher education. Vine, 31(2), 36-41.

Dahl, S. (2007). Turnitin ${ }^{\circledR}$ The student perspective on using plagiarism detection software. Active Learning in Higher Education, 8(2), 173-191.

Davis, M. (2007). The role of Turnitin within the formative process of academic writing. The Brookes eJournal of Learning and Teaching [online], 2(2). 
Embleton, K., \& Helfer, D. (2007). The plague of plagiarism and academic dishonesty. Searcher, 15(6), 23-26.

Gannon-Leary, P., Trayhurn, D., \& Home, M. (2009). Good images, effective messages? Working with students and educators on academic practice understanding. Journal of Further and Higher Education, 33(4), 435-448.

Gilbert, J. (2013). English for academic purposes. In G. Motteram (Ed.), Innovations in learning technologies for English language teaching. London: British Council.

Gilquin, G., Granger, S., \& Paquot, M. (2007). Learner corpora: The missing link in EAP pedagogy. Journal of English for Academic Purposes, 6(4), 1-25.

Goddard, R., \& Rudzki, R. (2005). Using an electronic text-matching tool (Turnitin) to detect plagiarism in a New Zealand university. Journal of University Teaching \& Learning Practice, 2(3), (Article 7) 58-63.

Gourlay, L., \& Greig, J. (2007). Avoiding plagiarism, developing identities: Responsibility, academic literacies and the curriculum. A JISCPAS Case Study, from http://researchrepository.napier.ac.uk/2612/1/gourlaygreig_cas estudy.pdf

Horovitz, S. J. (2008). Two wrongs don't negate a copyright: Don't make students Turnitin if you won't give it back. Florida Law Review 229, 60(1), 229-275.

Hyland, K., \& Hamp-Lyons, L. (2002). EAP: Issues and directions. Journal of English for Academic Purposes, 1(1), 1-12.

Jones, M. (2009). Back-translation: The latest form of plagiarism. Paper presented at the The 4th Asia Pacific Conference on Educational Integrity, University of Wollongong, NSW, Australia.

Keuskamp, D., \& Sliuzas, R. (2007). Plagiarism prevention or detection? The contribution of textmatching software to education about academic integrity. Journal of Academic Language \& Learning, 1(1), A91-A99.

Kisamore, J. L., Stone, T. H., \& Jawahar, I. M. (2007). Academic integrity: The relationship between individual and situational factors on misconduct contemplations. Journal of Business Ethics, 75(4), 381-394. 
Lea, M. R., \& Jones, S. (2011). Digital literacies in higher education: Exploring textual and technological practice. Studies in Higher Education, 36(4), 377-393.

Leask, B. (2006). Plagiarism, cultural diversity and metaphor: Implications for academic staff development. Assessment and Evaluation in Higher Education, 31(2), 183-199.

Lund, J. R. (2004). Plagiarism: A cultural perspective. Journal of Religious \& Theological Information, 6(3/4), 93-101.

Mahmood, Z. (2009). Students' understandings of plagiarism and collusion and recommendations for academics. WSEAS Transactions on Information Science and Applications, 8(6), 1348-1358.

Martirosyan, N. M., Hwang, E., \& Wanjohi, R. (2015). Impact of English proficiency on academic performance of international students. Journal of International Students, 5(1), 60-71.

McCabe, D. L. (2005a). Cheating among college and university students: A North American perspective. International Journal for Educational Integrity, 1(1).

McCabe, D. L. (2005b). It takes a village: Academic dishonesty and educational opportunity. Liberal Education, 91(3), 26-31.

McCabe, D. L., Butterfield, K. D., \& Trevino, L. K. (2006). Academic dishonesty in graduate business programs: Prevalence, causes, and proposed action. Academy of Management, Learning and Education, 5(3), 294-305.

McCabe, D. L., \& Pavela, G. (2004). Ten (updated) principles of academic integrity: How faculty can foster student honesty. Change: The Magazine of Higher Learning, 36(3), 10-15.

McCabe, D. L., \& Trevino, L. K. (1995). Cheating among business students: A challenge for business leaders and educators. Journal of Management Education, 19(2), 205-218.

McCabe, D. L., Trevino, L. K., \& Butterfield, K. D. (2001). Cheating in academic institutions: A decade of research. Ethics \& Behavior, 11(3), 219-232.

McGowan, U. (2005a). Academic integrity: An awareness and development issue for students and staff. Journal of University Teaching and Learning Practice (JUTLP), 2(3), 6. 
McGowan, U. (2005b). Plagiarism detection and prevention: Are we putting the cart before the horse. Paper presented at the Proceedings of the HERDSA conference.

McLean, P., \& Ransom, M. L. (2005). Building intercultural competencies: Implications for academic skills development. Paper presented at the ISANA.

Moore, T., \& Morton, J. (2005). Dimensions of difference: A comparison of university writing and IELTS writing. Journal of English for Academic Purposes, 4(1), 43-66.

Nagy, W., \& Townsend, D. (2012). Words as tools: Learning academic vocabulary as language acquisition. Reading Research Quarterly, 47(1), 91-108.

Neville, C. (2010). The complete guide to referencing and avoiding plagiarism. UK: McGraw-Hill Education.

Paquot, M. (2008). Exemplification in learner writing: A crosslinguistic perspective. In F. Meunier \& S. Granger (Eds.), Phraseology in foreign language learning and teaching (pp. 101-119). Amsterdam: Benjamins.

Park, C. (2003). In other (people's) words: Plagiarism by university students - literature and lessons. Assessment \& Evaluation in Higher Education, 28(5), 471-488.

Park, C. (2004). Rebels without a clause: Towards an institutional framework for dealing with plagiarism by students. Journal of Further and Higher Education, 28(3), 291-306.

Patel, A., Bakhtiyari, K., \& Taghavi, M. (2011). Evaluation of cheating detection methods in academic writings. Journal of Library Hi Tech, 29(4), 1-11.

Paynter, J., \& Mills, C. (2004). Academic plagiarism: An analysis of current technological issues. Retrieved 22 December 2014 http://www.orsnz.org.nz/conf39/Papers/PaynterJ.pdf

Pecorari, D. (2003). Good and original: Plagiarism and patchwriting in academic second-language writing. Journal of Second Language Writing, 12, 317-345.

Russikoff, K., Fucaloro, L., \& Salkauskiene, D. (2003). Plagiarism as a cross-cultural phenomenon. The CATESOL Journal, 15(1), 127-142. 
Savage, S. (2004). Staff and student responses to a trial of Turnitin plagiarism detection software. Paper presented at the Proceedings of the Australian Universities Quality Forum.

Sawir, E. (2005). Language difficulties of international students in Australia: The effects of prior learning experience. International Education Journal, 6(5), 567-580.

Singh, M. K. M. (2015). International graduate students' academic writing practices in Malaysia: Challenges and solutions. Journal of International Students, 5(1), 12-22.

Stapleton, P. (2010). Writing in an electronic age: A case study of L2 composing processes. Journal of English for Academic Purposes, 9(4), 295-307.

Stratilas, K. (2011). The evolving nature of support: A new horizon. Journal of Academic Language \& Learning, 5(2), A44-A49.

Šupak Smolčić, V., \& Bilić-Zulle, L. (2013). Patchwork plagiarism: A jigsaw of stolen puzzle pieces. Biochemia Medica, 23(1), 1618.

Velliaris, D. M., \& Warner, R. (2009, 1-4 December). Embedding 'learning guides' in a flexible delivery mode: Improving academic acculturation for international students at an Australian university. Paper presented at the 20th ISANA International Education Conference, Hotel Realm, Canberra, Australia.

Velliaris, D. M., \& Willis, C. R. (2014). Getting personal: An autoethnographic study of the professional identit(ies) of lecturers in an Australian pathway institution. In P. Breen (Ed.), Cases on teacher identity, diversity, and cognition in higher education (pp. 87-110). Hershey, PA: IGI Global.

Velliaris, D. M., Willis, C. R., \& Breen, P. (2015a). Academic reflections: Disciplinary acculturation and the first year pathway experience. In P. N. Shrestha (Ed.), Current developments in English for academic and specific purposes: Local innovations and global perspectives (pp. 217-235). Reading, UK: Garnet Publishing Ltd.

Velliaris, D. M., Willis, C. R., \& Breen, P. (2015b). Reflections on the impact of social technologies on lecturers in a pathway institution. In V. Benson \& S. Morgan (Eds.), Implications of 
social media use in personal and professional settings (pp. 131-155). Hershey, PA: IGI Global.

Velliaris, D. M., Willis, C. R., \& Pierce, J. M. (2015). International student perceptions of ethics in a business pathway course. In F. M. Ribeiro, B. Culum \& Y. Politis (Eds.), New voices in higher education research and scholarship (pp. 234-253). Hershey, PA: IGI Global.

Yeo, S., \& Chien, R. (2005). The seriousness of plagiarism incidents: Making consistent decisions across a university. Paper presented at the 2nd Asia-Pacific Educational Integrity Conference.

Zhang, Y., \& Mi, Y. (2010). Another look at the language difficulties of international students. Journal of Studies in International Education, 14(4), 371-388.

DONNA M VELLIARIS, $\mathrm{PhD}$ is Academic Advisor at the Eynesbury Institute of Business and Technology (EIBT). EIBT is a specialist pre-university institution where international students work towards the goal of Australian tertiary entrance. Donna's research extends to diverse themes including: Bronfenbrenner's Human Ecological Theory; international/ transnational students; the first-year experience in higher education; and schools as cultural systems. She has lived, studied and worked in over 40 countries across the globe. Donna is co-editor of a Handbook of Research on Study Abroad Programs and Outbound Mobility.

PAUL BREEN, PhD is a Senior Lecturer in The University of Westminster Professional Language Centre, London. $\mathrm{He}$ is a published author, and writer of numerous articles and blogs in both the academic and popular domains. His research interests are in the area of teacher education, educational technology and teacher identity. He is the author of Cases on Teacher Identity, Diversity, and Cognition in Higher Education (2014), and has taught across contexts and continents in further and higher educational environments. Email: p.breen@westminster.ac.uk 